\title{
SMALL BUSINESS AND ITS PROBLEMS IN THE UNITED KINGDOM
}

\author{
D. G. RICE*
}

I

\section{Definttion, Organization, and Human Aspects of Small Busingss}

Any examination of the problems of the small business in the United Kingdom necessarily presupposes an acceptable definition of what constitutes "small business." "Small," like "big," is a relative term. What is small in one context is large in another, and what is insignificant to one person appears immense to someone else. Indeed, any attempt at prescribing the extent to which a business can grow before it ceases to be small is liable, in the very nature of things, to meet with criticism based on purely subjective considerations. Nevertheless, however difficult the task may be, a definition of the term "small business" is a prerequisite of any discussion of its problems. But before we attempt a definition, it is necessary first to review briefly the different legal structures under which the commercial life of Great Britain is conducted.

The simplest and least sophisticated form of business is that carried on by an individual trader acting on his own account or in partnership with one or more others. Such a business structure does not, of course, confer limited liability, and, being unincorporated, the intrinsic difficulties of obtaining capital are further aggravated by the severe restrictions imposed on the mortgaging of chattels by the Bills of Sale Act, $1878-82,{ }^{1}$ and the Bankruptcy Act, $1914 .{ }^{2}$ Moreover, it must also be remembered that a partnership, ${ }^{3}$ not having perpetual succession independent of its members, is liable to dissolution on the voluntary determination, death, or bankruptcy of any member (and by way of corollary, the interest of each member is necessarily nontransferable); that the need for each member to exercise managerial functions inevitably precludes the membership of the firm from expanding too far; ${ }^{4}$ and that the personal liability ${ }^{5}$ attaching to each member for the business debts of the undertaking acts as a brake on the admission of further partners in the absence of

* B.A. I950, LL.B. x951, M.A. I955, Cambridge; Ph.D. 1956, London. Of Lincoln's Inn, Barristerat-Law; Company Director. Contributor to legal periodicals.

${ }_{41}^{1} \& 42$ VICT. c. 3 I, and $45 \& 46$ VICT. c. 43 .

${ }^{2} 4$ \& 5 Geo. 5 , c. 59 .

${ }^{3}$ Whose legal structure is now governed by the Partnership Act, 1890,53 \& 54 VIcr. c. 39.

-In any organization, there is a natural limit to executives of roughly equal standing. Moreover, the law acknowledges the situation by restricting, at the moment, the number of partners to 20 .

"Since the Limited Partnership Act, 1907, 7 EDw. 7, c. 24, it has been possible to have partnerships with limited liability where a partner does not take any active part in the business. They have not, however, proved very popular in practice. The sleeping partner will automatically become liable if he even slightly intermeddles wth the firm's affairs, and when things are going badly, there is a great temptation to try to save the sinking ship. 
complete confidence in their ability and integrity. Accordingly, the unincorporated concern is not a very satisfactory medium for the development of industrial empires. It is, indeed, a structure suitable only for professional firms and commercial businesses conducted on a very modest scale.

By far the most important organizational form for commercial and industrial undertakings today is the limited liability company. It can assume either a private or a public form, the former having received official recognition in the Companies (Consolidation) Act, rg08. The private company is generally, though not necessarily, smaller than the public company and is frequently little more than the incorporated embodiment of the old-fashioned partnership. But each "partner" (now called "director") can feel sure that his private fortune cannot be called upon to defray the debts of the business, and he can at any time retire or die without disruption to the business as such. He cannot, of course, withdraw his money, ${ }^{7}$ as he could in the case of a partnership, but he can always transfer his interest elsewhere (though it does not necessarily follow that the value of his shares will correspond to that of the capital he contributed in the first place).

Because of the family association of private companies, the law has from the start imposed limitations on the flexibility of their constitution. It has restricted the membership to fifty (excluding present and past employees), curtailed the right to transfer shares, and prohibited any invitation to the public to contribute capital. ${ }^{8}$ The essential intimacy of private companies and their affinity to partnerships made it only reasonable to preserve their character by restricting their connection with the investing public at large. And to a large degree, the law only did what the members wanted anyway-i.e., it debarred "outsiders" from membership.

By way of corollary, the law originally exempted all private companies from compliance with certain formalities designed to protect the investing public, and in particular from the obligation to file accounts. Unfortunately, certain large public companies began to cloak their activities behind a front of private companies, thereby forcing the law to distinguish between those companies that were really genuine family concerns and those that were not, now known, respectively, as exempt and nonexempt companies. The latter have lost most of the privileges belonging to the preI948 private companies, and in particular are deprived of their exemption from the obligation to file accounts. The exact definition of what constitutes an exempt private company is contained in section 129 and schedule seven of the Companies Act, rg48.

Although in the case of the family private company, management and ownership are still strongly connected, the position is generally otherwise with the older legal

${ }^{\circ} 8$ EDw. 7, c. 69. For a full and erudite discussion of the English private company, see Professor L. C. B. Gower's contribution to the symposium on The Close Corporation, i 8 LAw \& Contemp. ProB. 534 (1953).

7 Subject to a return of capital under $\S 66$ of the Companies Act, I948, Ir \& 12 GEo. 6 , c. 38 , or a winding-up.

${ }^{8}$ See Companies Act, 1948, Ir \& 12 GEo. 6, $\S 28$ and pt. II, art. 2, of table A. 
creation-the public limited company. Here the investing public are invited to subscribe funds, in return for which they receive dividends but assume only a passive role in relation to the affairs of the company. In consequence, the law requires full disclosure to be made of the company's accounts to the world at large, and no restriction is placed on the transferability of its shares. Such companies can be classified into those that enjoy a public quotation and those that do not. By a public quotation, we mean the appraisal of the company's stocks and shares on the London or any provincial stock exchange.

Generally speaking, all the large companies either have their share capital publicly quoted or are subsidiaries of companies in this position. Numerically, however, private and nonquoted companies preponderate by far. According to the pamphlet entitled Company Income and Finance 1949-53 compiled by The National Institute of Economic and Social Research, London, in 1953, there were 270,269 companies with share capital, of which only II,444 were public companies, and of these a mere 3,000 or so actually enjoyed a quotation. ${ }^{9}$

However, this vast numerical difference should not lead the reader to underestimate the importance of the quoted sector of industry. An attempt has been made by the National Institute to assess the relative importance of quoted companies as against the rest. With respect to the paid-up capital, those companies whose securities are quoted account for $f_{2,740}$ million-i.e., forty-three per cent of the total of $f_{0} 6,412$ million for all companies and sixty-seven per cent of the total of $f_{4}, 062$ million for all public companies. Viewed from the standpoint of profits, the quoted sector earned during the period $1949-53$ fifty-six per cent of the total corporate profits (the figure for manufacturing industry as distinct from building and distribution being seventy-one per cent), and the percentage rose during the quinquennium from fifty-one to sixty per cent. As for personnel, the National Institute estimates that something like fifty-eight per cent of the total manpower absorbed in manufacturing ${ }^{10}$ industry is employed by quoted companies; or, if we take into account the greater productivity of the large concern per person employed and measure in terms of "added value" or "net output," we find that the share attributable to quoted companies would amount in all probability to about fifty to fifty-two per cent of manufacturing industry. Finally, if we take as our criterion the number of persons employed in manufacturing establishments, where the average number is only sixty, the corresponding figure for establishments operated by companies whose securities are quoted amounts to no less than 340. Clearly, then, it is the quoted company that is the real giant of British economic life.

Having examined briefly the different legal structures under which commercial enterprise is conducted in the United Kingdom, we have yet to determine what

\footnotetext{
${ }^{9}$ Companies are only included in the survey if their main activity is directed to manufacturing, building, or distribution in the United Kingdom. Thus, companies engaged in banking, insurance, finance, property, shipping, and agriculture have been excluded, and the same is true of companies opcrating principally overseas (e.g., oil corporations). Furthermore, no cognizance is taken of nationalized industries.

${ }^{10}$ No figures are available for distributing organizations.
} 
constitutes "small business." Quite clearly, both the undertaking of the sole trader and the partnership must come within this classification. The very nature of these forms of business structure prevents any substantial growth. Moreover, it is reasonable to regard private companies in the same light. Admittedly, it is possible to find undertakings of this kind commanding very considerable financial resources and employing many hundreds of workers. But that is exceptional. Moreover, as we have demonstrated statistically, even where public companies are concerned, it is those enjoying a stock exchange quotation that can generally be said to qualify as the giants of the industrial and commercial life of the United Kingdom. Accordingly, in defining what constitutes small business, we will regard as falling within that classification all enterprises that do not enjoy a quotation of their shares on the London or any provincial stock exchange.

Now that we have defined what constitutes small business, we can proceed to consideration of the problems that are peculiar to it. Our discussion will have to embrace all the different legal structures to which we made reference; but it will simplify our examination if we direct our remarks to the private limited company (which is, in fact, the most common form under which small business is conducted), making qualifications where the other types of structure so require.

The small business tends to be family in character, and from this, there emerge two human problems that perennially confront it. The first involves the frailties of man's nature. Jealousy, though endemic in all human relationships, seems to be particularly pronounced where families are concerned, and hence the family business is wide open to the undermining influence of family feuds. Time and again, where total strangers would work in complete harmony in their business affairs, families find themselves involved in petty squabbles within themselves. One of the inherent weaknesses of a family concern is that family considerations tend to get projected into a business relationship. Thus, the commercial and intellectual gifts of one brother or cousin tend to be equated within the family to those of another brother or cousin. In the family scale of values, one brother or cousin is equal to another brother or cousin, the realities of the situation being totally disregarded. Moreover, even where lip service is paid to the undoubted differing abilities of different members of the family, we still find deeply ingrained in the family subconscious the unyielding conception of family equality. Now, in the highly competitive world of industry and commerce, there is no scope for any internal disharmony. A ship divided must founder. It would, indeed, be interesting to know (though, of course, impossible to ascertain) how many family businesses have over the years failed through sheer internal discord.

The second difficulty of the small business is that its success or failure tends to depend to an inordinate extent on the personality of the managing director. ${ }^{11}$ In fact, the smaller the business, the greater the dependence. For quite clearly, the scope for delegation of responsibility and employment of high-grade personnel at com-

\footnotetext{
${ }^{11}$ Equivalent to the American president.
} 
mensurate salaries is correspondingly reduced. Where a business is essentially family in character, the managing director will usually have to be drawn from the family. The business is rarely of such a size as to allow management to be divorced from ownership. Rarely is it in a position to employ on a strict managerial basis an executive of sufficient calibre that the whole control of the enterprise can be safely entrusted to him. Although the original managing director of a small business which has been successful may have been a man of great drive and ability, there is no guarantee that his son or nephew will possess similar qualities. In contrast, in the case of a large concern, the undertaking is run by a managerial class; and the larger the company, the less dependent it is on the personality of any one man. In fact, the departure of the managing directors of most of the leading industrial concerns would, it is submitted, have little impact on their immediate profitability.

II

\section{Finance of Smali Business}

\section{A. Raising of Capital}

Leaving the human problems inherent in the small business, we turn to another difficulty, no less great-that of raising capital. The two principal sources of permanent capital are to be found in the investing public and in the large financial institutions with pension and other funds ready to invest. But in our discussion above of the legal status of the private limited company, we pointed out that this form of organization is precluded from inviting the public to subscribe for any of its shares or debentures. ${ }^{12}$ The consequence of this is that one of the two main sources of permanent capital is automatically cut off from the private company. The small business simply cannot resort to the investing public. ${ }^{13}$

However, there is no legal embargo on an application to individual institutional investors. But here, again, the chances of success are slight, for the legal status of the private company militates against any support from this quarter. As has already been explained, the private company is compelled to restrict the right to transfer its shares, and must limit the number of its shareholders (excluding present and certain past employees) to fifty. The result is that its shares are sadly lacking in marketability and hence are not particularly attractive to institutional investors, since they cannot easily realize their investment. Of course, this does not imply that the institutions never hold unquoted securities. They are prepared to include in their portfolios some unquoted securities (particularly preference shares redeemable over a fifteen to twenty-year period), but the proportion is severely limited, ${ }^{14}$ and their acceptance of

${ }^{12}$ However, it must be remembered that even if it were allowed legally to make a public issue (as are the sole trading concern and the partnership), it is doubtful whether economically this would be a practical proposition in the vast majority of instances. It would certainly not be so in the case of the sole trading concern or the partnership.

${ }^{13}$ Reference is made to resort by means of an open invitation to the public at large. The company can, of course, approach certain members of the investing public on a private basis.

14 It should be pointed out in fairness, however, that with the continued growth in pension funds and the need to find higher yields than those obtainable from gilt-edged securities on a proportion of their investments, more funds are being made available for investment in unquoted securities. 
them is often subject to the condition that the company will, at its own expense, apply to the stock exchange within a fixed period of two or three years for a quotation. Moreover, when they are prepared to hold shares whose marketability is severely restricted, the return they require by way of compensation must be correspondingly higher. The result clearly is that the cost of obtaining institutional support, where it is forthcoming, is greater for the small business than the large. And, in addition, since most institutional investors are nonexempt companies, if by the financial transaction they control one-fifth or more of the total voting power of the private company, ${ }^{15}$ the latter company loses its exempt status (assuming, as is usually the case, it, in fact, previously enjoyed this advantage) and with it, the benefit of not having to file a balance sheet at the Registry of Companies.

Although a private company is prevented by law from inviting the public to subscribe for its shares, it is not precluded from having its securities privately placed by stockbrokers who specialize in this class of business. However, it is difficult to arrange this unless a public quotation is probable in the near future. Even here, the clients require an above-average yield, so that the cost to the small business of raising capital (in so far as it is available to it) is appreciably higher than it is to its larger rival.

Quite apart from their lack of marketability, shares in private companies are singularly unattractive to investors on another score. The private character of this type of company tends to undermine the position of those who have subscribed capital to it. When once the investor has parted with his money, he renounces all entitlement to it and takes in exchange a bundle of rights. Although these rightsincluding, as they do, rights of voting, rights to dividends, and rights on a windingup-are extensive, they are not identical with ownership of the capital sum subscribed. Hence, the investor's financial stake in the company must be measured not by the monetary value of the capital he has put up, but by the worth of the rights which he enjoys in the company. If he is a minority shareholder, his legal position may be far from enviable. In spite of the recent extension of minority protection by the House of Lords in Scottish Cooperative Wholesale Society, Ltd. v. Meyer ${ }^{16}$ it is a commonplace of English company law to say that, where an unscrupulous majority is intent on oppressing the minority, it is unlikely to be balked in the attempt.

However, as far as public companies are concerned whose shares are quoted on a stock exchange, the chances of flagrant oppression are considerably reduced. The mere fact that such companies are large and function very much in a public climate tends to cause their boards of directors to be men of high principles. Their office is semipublic, and, generally speaking, they regard their duties as those of trustees. And, again, an oppressed minority can find very considerable protection in the financial press. Any flagrant instance of oppression will certainly be revealed there; and, quite apart from the high moral principles usually associated with directors of

${ }^{15}$ Companies Act, 1948, II \& I2 GEo. 6, sched. VII, para. 7 .

${ }^{10}\left[\mathrm{r}_{95} 8\right] 3$ W.L.R. $4^{\mathrm{O}} 4$ (the case dealt with interpretation of $\S 210$ of the Companies Act, 1948). 
quoted public companies, there are few businessmen who would wish to see their activities publicly exposed by various financial correspondents only too eager to bring to the light of day any shady business which they may think they have discovered. Moreover, from a practical standpoint, the mere fact that a public quoted company will almost certainly have hundreds, if not thousands, of shareholders, helps to prevent the possibility of minority oppression. The mere deployment of interests militates against a ganging-up of an unscrupulous majority.

In the case of a private company, however, none of these safeguards applies. There is not the same guarantee of high-principledness in the directors; there can be no exposition of oppression in the financial press; and, since the number of shareholders is strictly limited, the chances of one or two members combining to oppress the others are immensely enhanced. It is not surprising, then, to discover that on this score as well as lack of marketability, the private investor is reluctant to contribute funds to an unquoted company; ${ }^{17}$ and, even if he does so, the compensatory reward must be such as to render the cost of raising capital for a small company considerably higher than it is for its large quoted counterpart.

Since it is difficult for a private company to raise permanent funds from institutional or private investors, certain semiofficial bodies have been set up to assist small and medium-sized firms. ${ }^{18}$ The most important, as far as the small business is concerned, is the Industrial and Commercial Finance Corporation (ICFC) which was established in 1945 with the support of the Bank of England and the London and Scottish Clearing Banks. Its object is to provide small and medium-sized companies, unable to obtain permanent funds from other sources, with sums of between

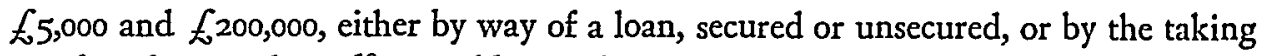
up of preference shares. ${ }^{19}$ In addition, the ICFC may require as part of the arrangement that it shall have the option of subscribing for a small proportion of the equity capital on certain prescribed terms. Moreover, bonus debentures may be created from unappropriated revenue reserves and sold to the ICFC on the basis of their redemption over a twenty-year period. ${ }^{20}$

The object underlying the creation of the ICFC is, of course, to prevent new development being concentrated unduly within the ambit of strongly entrenched concerns. The value to the economy of the new small business is acknowledged in the setting up of the ICFC. Needless to say, before lending money, the Corpora-

\footnotetext{
${ }^{17} \mathrm{He}$ will generally only do so where there is complete confidence and trust or where family considerations outweigh normal commercial prudence.

${ }^{18}$ It should also be noted for completeness that apart from any help from this quarter, permanent working capital can be obtained by private companies from certain indirect sources. If they happen to own freehold property, they can mortgage it, or alternatively they can sell it outright taking back a lease at a rack rent. Or negatively, they can sometimes save working capital by renting factory space on one of the government-sponsored trading estates. However, these factors do little to alleviate the fundamentally difficult position of the small business in raising permanent capital.

${ }^{10}$ It also provides the services of experienced and qualified advisors and technicians. It does not, however, interfere with the management of the company.

${ }^{20}$ The debentures may confer a first charge on the fixed assets of the company and a second floating charge. This will not prejudice the obtaining of bank credit, in that the bank may take a first floating charge and a second charge on the fixed assets.
} 
tion carries out a full survey, and may require the right to appoint a director. At any event, it will normally call for monthly figures showing the financial and trading position of each client, which will, of course, be to the interest of both parties. ${ }^{21}$

Although the setting up of the ICFC is a very welcome step in the direction: of providing finance for the small and medium-sized business, ${ }^{22}$ fundamentally the raising of permanent funds still remains a problem of great difficulty. Indeed, the opportunity for expansion would largely be denied the small business were it not for the reasonable availability of temporary financial accommodation. There is nothing to stop the small business from resorting to the bank. ${ }^{23}$ In fact, many big businesses owe their success, in very large measure, to the sustained support of their bank throughout their whole period of growth, from insignificance to a position of national or international standing. However, although the banks are willing to accommodate small businesses, ${ }^{24}$ they will be particularly cautious in their dealings. with them. For example, they may and usually do require personal guarantees from the directors-i.e., the banks go behind the veil of incorporation. They require as proof of the directors' confidence in the project for which the loan is required an acceptance by the directors of personal liability for repayment. Thus, in order to obtain financial help, the owners of the small business have to surrender one of the most valuable advantages of incorporation-limited liability. ${ }^{25}$ This is but an illustration of the age-old principle that there is one rule for the rich and another for the poor.

Apart from bank loans (and to a limited extent, where the standing of the company is good enough, bills of exchange), fundamentally the private company is dependent for its expansion on ploughed-back profits. Admittedly, it may often acquire equipment on hire-purchase, thereby obtaining immediate use of the equipment but paying for it out of earnings. However, the charges for this facility are generally penal. Accordingly, a private company must exercise great restraint in its dividend policy. For many years, the shareholders must be prepared to sacrifice the present for the future. This policy may often have to endure for the best part of a lifetime; yet, there is no other real way of accumulating the necessary reserves out of which sustained growth can emerge. The extent to which profits can be ploughed back. into the business will depend on the extent to which the company is allowed to retain them. At once, we are brought face to face with the problem of taxation.

$2 x$ The ICFC has now been supplemented by a number of other bodies such as Estate Duties Investment Trust Ltd., to which reference is made, note 44 infra, the Charterhouse Industrial Development Co. Ltd., Private Enterprises Investment Co. Ltd., and Glasgow Industrial Finance Co. Itd.

22 The Corporation's loans and investment holdings on March 3I, I958 exceeded $f_{34}$ million and its. customers amounted to more than 620 .

${ }^{23}$ The sole trader and the partnership firm will find it more difficult to obtain bank accommodation: than will an incorporated body, in that the latter can grant a floating charge over its assets by way of security.

"24 But not so (or only to a very limited extent) during a period of "credit squeeze," such as that: through what the United Kingdom has just passed.

${ }^{25}$ The surrender is restricted, of course, to the amount of the loan. 


\section{B. Problems of Taxation}

Fundamentally, the weight of taxation falls more heavily on those companies which do not have the benefit of a stock exchange quotation. ${ }^{26}$ The rationale behind the disparity of treatment is the determination of the Inland Revenue to prevent wealthy men from carrying on trading activities under cloak of private limited companies, with the full benefit of the tax concessions granted to genuine bona fide trading corporations. ${ }^{27}$ Accordingly, in assessing unquoted companies for taxation, the Inland Revenue goes behind the veil of incorporation and looks to the "control" of the company. In this short survey of the problems of the small business in the United Kingdom, it is inappropriate to attempt to encompass all the intricacies of tax law connected with the form of business structure we are considering. We will simply sketch some of the principal problems that confront it.

The first difficulty is that under sections $245-64$ of the Income Tax Act, $1952,{ }^{28}$ a surtax direction order may, in certain circumstances, be made by the Special Commissioners against any company incorporated in the United Kingdom if it is controlled ${ }^{29}$ by not more than five persons (of whom certain classes, such as relatives, are deemed to be one) and if it is not a subsidiary of a company which is itself immune from a direction, and if the public is not substantially interested in it (which means, in practice, that the public do not hold at least twenty-five per cent of the equity capital). The liability of such a company to a direction order will arise when, in the view of the Special Commissioners, a reasonable ${ }^{30}$ distribution of profits has not been made by way of dividend. The effect of a direction is that, in so far as surtax computations are concerned, the whole profits will be apportioned among the shareholders, who will be assessed accordingly. Then, unless the latter elect to pay the tax, it will be recovered from the company itself.

Clearly, there are very few family concerns which will not be caught by these provisions (particularly as relations are deemed to be one legal person), and the only practical way for a company of reasonable size to escape the consequences is to obtain a quotation for twenty-five per cent of its equity capital. However, since the war, the above provisions and their forerunner, section 21 of the Finance Act, 1922, ${ }^{31}$ have, until comparatively recently, had little effect on small businesses because of what is known as the "Chancellor's Umbrella." In 1947, when under a Socialist government the political climate was strongly against dividend distribution, the late Sir Stafford Cripps (then Chancellor of the Exchequer) gave an assurance in Parliament that in the case of bona fide trading concerns, where no tax-avoiding device was in evidence, no new direction order would be made, even if profits grew without any corresponding dividend increases. However, in 1957, the protection of the Chancellor's

${ }^{20}$ Which, for the most part, will be the private companies.

27 They must not be allowed to use such a cloak for reducing or eliminating their liability to surtax.

${ }^{33}$ I5 \& I6 Geo. 6 and I Eziz. 2, c. ro.

${ }^{29}$ For a definition of the meaning of "control," see $i d . \$ 256$.

${ }^{30}$ What is reasonable will depend, of course, upon the circumstances of each individual case.

${ }^{31} \mathrm{I}_{2}$ \& $\mathrm{I}_{3}$ GEO. 5, c. I7. 
Umbrella was specifically withdrawn, thereby exposing small businesses to the hazard of the working of sections $245-64$. It is too early to say what in practice has been the effect of the change, but, in theory at least, the small company is prevented from ploughing back profits to excess. As the small business is so dependent on accumulated reserves, the withdrawal of the Chancellor's Umbrella must tend to curb the growth of the private company.

Apart from income tax, all limited companies are liable to profits tax on annual earnings over and above $\oint_{2,000 .}{ }^{32}$ Private companies, however, are apt to meet with much more severe treatment in this respect than do those of their competitors which enjoy a quotation for their share capital. Many private companies are "director-controlled"-that is, more than half the voting power is controlled by the directors. When this happens, certain items are disregarded as expenses in computing the company's earnings for profits tax purposes. Thus, loans to shareholders are treated as a distribution subject to profits tax; and debenture interest is not an allowable expense if it is in favor of a director other than a full-time service director.

Far more important is the inadmissibility as a trading expense of directors' remuneration beyond certain specified figures. Although the earnings of full-time service directors-directors who are employed full time in some managerial or advisory capacity and who do not own or control more than five per cent of the equity capital-will be disregarded in computing profits tax, the remuneration of other directors will invariably be taken into account, subject only to relaxation in the following two respects. First, a deduction will be admissible to the extent of $£ 2,500$ or fifteen per cent of the assessed profits (limited, however, to $£ 15,000$ ), whichever figure is the higher; and, secondly, where there are "qualifying" directors -directors who devote substantially the whole of their time to the service of the company in some managerial or other capacity-the company can, by way of an alternative to the relief just mentioned, claim the right to deduct from profits directors' remuneration in accordance with the following formula: $:^{33}$

$£ 2,500$ for one qualifying director;

$£_{4}, 000$ for two qualifying directors;

f5,500 for three qualifying directors; and

$£ 7,000$ for four or more qualifying directors.

Needless to say, in many cases, the salary scale admissible under the above formula for "qualifying" directors is quite unrealistic. Accordingly, the director-controlled private company ${ }^{34}$ will find itself severely penalized in the computation of its profits

\footnotetext{
so The business of persons trading as individuals or partners will not be liable to this impost; nevertheless, the owners will be liable to surtax, which on incomes over $£ 15,000$ per annum can be at the rate of $92.5 \%$.

${ }^{33}$ This formula is subject to safeguards to prevent the board from being artificially augmented by qualifying directors with purely nominal salaries in order to enable the "real" directors' remuneration to be kept within the allowable deduction.

${ }^{34}$ The penalty will also apply to a public company, provided its share capital is not quoted. Once a quotation is obtained, the handicap of being director-controlled is at once dispelled.
} 
tax liability. ${ }^{35}$ Admittedly, on annual profits between $£^{2,000}$ and $f_{0} x 2,000$, an abatement relief is obtainable, ${ }^{36}$ but this is unlikely to offset the penal effects of restricting the extent to which directors' remuneration is admissible as an expense for profits tax purposes. ${ }^{37}$ Once again, we have a case where the private company is oppressed by taxation more seriously than is its quoted counterpart; and, as was indicated earlier, the more it is prevented from accumulating profits, the more the opportunities for expansion will be curtailed, since the private company depends so vitally upon ploughed-back profits for its development.

Again, a private company is apt to find itself prejudicially affected by the death of a substantial shareholder; the need to satisfy the crippling demands made in respect of death duties may well result in the break-up of the company or its absorption by a larger concern, its character and individuality thereby being lost forever. The position is at its worse where section 46 of the Finance Act, $1940{ }^{38}$ applies. Under this section, where a person has contributed assets to the company (as, for example, will be the case with the founder), regardless of whether he owns any shares at his death or does not do so, his estate will be charged with that proportion of the company's assets which the value of all benefits received by him during the five years prior to his death bears to the total income of the company during that period; and the company will have to account for the tax. Thus, if a company, during the five years in question, should earn $£_{50,000}$ and the deceased should have received $£_{25,000}$ in remuneration and other benefits, then, regardless of the extent of his shareholding (which may in fact be nonexistent), he will be deemed to own half the company, and the company will be liable accordingly. Fortunately, however, it is not the practice of the Estate Duty Office to enforce this provision where the contribution to the company's assets has been made in the normal course of business and there has been no attempt to adopt any tax avoiding device. Instead, it will normally be satisfied with a valuation under section 55 .

Under that section, where the deceased, within five years of his death, had con-

${ }^{35}$ The directors of a director-controlled company (if they own or can influence more than $5 \%$ of the equity capital) will also find themselves under a severe handicap from the point of vicw of pensions. They cannot take part in "top-hat schemes" (schemes designed for higher paid executives and requiring in each case specific approval by the Inland Revenue), where contributions are treated as an expense for the company and are not regarded as benefits in the hands of the persons for whom the pensions have been taken out. However, the worst effects of this have been mitigated by the Finance Act, $\mathrm{x} 956,4$ \& 5 Exiz. 2, c. 54, under which controlling directors, in common with other self-cmployed persons, can enter pension schemes which do not fall far short of the "top-hat schemes" in the benefits they confer.

It should also be noted that controlling-directors will probably find the Inland Revenue paying particular attention to any benefits in kind that they may have received.

${ }^{30}$ Arrived at (where there is no franked income) by taking one-fifth of the amount by which the profits fall short of $f_{0} 12,000$.

${ }^{37}$ Moreover, the Inland Revenue has wide power to circumvent the effects of profits tax avoidance devices.

${ }^{38}{ }_{3} \&{ }_{4}$ GEO. 6, c. 29. 
trol $^{39}$ of the company, his shares will be valued on an assets basis-that is, they will be deemed to be fractions of the company's total net assets. Of course, it is exceptionally difficult to value a private company's assets $;^{40}$ and, even if this hurdle is successfully negotiated, to regard someone's shares as worth a proportionate part of the assets is usually quite unrealistic. The holder or his personal representatives normally could never hope to get this price on the open market. ${ }^{41}$ Fortunately, under the provisions of the Finance Act, $1954,{ }^{42}$ certain reliefs are obtainable; but, nevertheless, death duties may be so great as to cause the company to be broken up or sold to a larger concern. So may end a life's work!

Moreover, even where section $55^{43}$ is not applicable, the deceased having never had control of the company, the valuation of shares in private companies, which must be arrived at on the principle of an imagined sale between a willing buyer and a willing seller, may be quite unrealistic in view of the restrictions necessarily imposed on the transfer of such shares. In fact, the shares may sometimes be quite unsalable. Once again, death duties may have devastating effects on the whole character and personality of the company. ${ }^{44}$

A quoted company, however, is quite unaffected by the above considerations. Neither section 46 nor section 55 can apply, and the valuation given to the shares will be that ruling on the stock exchange at date of death. Under no circumstances will the Inland Revenue have recourse to the company's assets.

One final point should be made about taxation as far as it concerns the small business. Until the Finance Act, $1958,{ }^{45}$ the amount payable by way of profits tax on a company's earnings was thirty per cent, with relief at the rate of twenty-seven per cent on earnings not distributed. This represented a major concession to the private company as against its quoted counterpart, in that-since the former was so much more dependent for its development on the accumulation of past profits-the policy it generally adopted of declaring low dividends resulted in a considerably reduced liability to profits tax. However, since $195^{8}$, a flat rate of ten per cent has been imposed, regardless of whether or not profits have been distributed. This change must prejudice the position of the small business in its struggle to find capital for its development. Act.

${ }^{30}$ Command of a bare $50 \%$ of the voting power will suffice. For a definition of "control," see the

${ }^{10}$ These difficulties are discussed in In re Holt, [1953] 2 All E.R. 1499. See further Dean v. Prince, [1954] Ch. 409 (C.A.), and Trew, Executors and the Private Company, [1957] J. Bus. L. 26, 30-32.

${ }_{12}$ The holding of at least $75 \%$ of the voting equity is, commercially speaking, a minimum prerequisite for any direct equation between share values and the company's assets.

${ }^{42} 2$ \& 3 ELIz. 2, c. 44 .

${ }^{4}$ For completeness, it should be noted that neither $\S 55$ nor $\S 46$ apply while a company is not privately controlled within the test prescribed by $\$ 21$ of the Finance Act, 1922 (as slightly extended).

"However, an attempt has been made to mitigate the position by the setting up of Estate Duties Investment Trust Ltd. ("Edith"), financed by the ICFC and certain insurance companies and investment trusts. The purpose of "Edith" is to provide "a reliable and neutral means for acquiring and holding as an investment" shares in private companies, without interfering with their management.

46 \& 7 ELIz. 2, c. 56. 
III

\section{Economic Difficulties of Small Business}

\section{A. Technological Advances in Distribution}

So much for the problems of small businesses that stem fundamentally from their legal status! We must now turn to the economic difficulties that face them at the present time. It should first be mentioned that the small business tends generally to be found among manufacturers of consumer products and retailers, rather than among producers of capital goods. ${ }^{46}$ Normally, the restricted funds available to the private company either preclude entry into the latter field or, at any rate, drastically curtail any significant development therein. Thus, it is unrealistic to imagine a small company embarking on steel production, motor car or aircraft manufacture, mining, chemical engineering, shipbuilding, or similar undertakings.

In the manufacture and retailing of consumer goods, however, the situation is totally different. In fact, the small shop is one of the traditional manifestations of the small business. It is here, perhaps most of all, that the small concern is facing the impact of new techniques. In recent years, the principles of mass-production have spilled over in full force to the distributing side of economic life in the United Kingdom. In an attempt to cut the costs of selling (particularly as far as labor is concerned), we have witnessed the rapid growth of the chain store and the development of the supermarket. ${ }^{47}$ They are both based on the principle that the purchaser shall do the work of selection and the seller will merely lay out the goods. Traditional selling methods and their high cost are thereby eliminated. Hence, in a chain store, low-grade assistants can be employed whose principal function is to collect the money for purchases and stop petty pilfering; or in the case of a supermarket, there are no sales assistants at all in the traditional sense. The goods sell themselves, and the management merely provides the requisite organization. In other words, techniques analogous to those commonly associated with production methods are being applied to distribution; and, needless to say, the source of this movement is to be found in the United States of America.

The result of this development has been to prejudice the position of the small retailer in the United Kingdom. Not merely are the chain store and the supermarket able by their vast turnover ${ }^{48}$ to obtain more favorable buying terms, but at

${ }^{60}$ The small builder is perhaps the most obvious exception.

17 The supermarket must be distinguished from the self-service store, which, though based on the same principle that the customer will select his purchases, is much smaller in size. A supermarket must be at least 2000 sq. $\mathrm{ft}$. in area, and, in fact, there is a tendency for it to be increased in the United Kingdom from the usual 3000-6000 sq. ft. to 4000-8000 sq. ft., though even this leaves it far behind the giants of the United States.

Although there is a slight saving in labor costs relative to the increased turnover in the commoner self-service store, it is in the supermarket, with its increased scale of operations, allowing specialization of function, that the real labor economies are obtained.

"Due in essence to "impulse buying," there being such a vast display of goods attractively laid out under one roof. 
the other end of the line, they are able to cut their selling costs. ${ }^{49}$ In consequence, they can afford to sell to the public at lower prices, without any interference with their profit margins. ${ }^{50}$ Indeed, the chain stores, such as Marks \& Spencer's, have consistently adopted a policy of selling their goods at prices which are exceptionally low, having regard to the quality offered. Of even more importance for the small retailer is the impact of the supermarket, with its technique of introducing "loss leaders"--well-known branded goods deliberately sold below their listed price to induce customers to enter the shop and simultaneously to purchase other wares at the correct price. This kind of competition, coupled with the intrinsic attraction to the customer of the self-service method of shopping, the small distributor with his traditional method of selling finds it immensely difficult to withstand. ${ }^{51}$ In fact, since 1950, when the self-service technique first began to make an impact on the United Kingdom-though the supermarket did not begin till after $1954^{52}$-it has been estimated that some 5000 grocers have been put out of business.

Moreover, it is usually quite unrealistic for the small concern to retaliate against the supermarket by itself adopting this medium; the cost-estimated at about $£_{5} 5^{0,000}$ for setting up an average-size supermarket-will generally prove completely prohibitive. Admittedly, the small concern, with its counter service, can give the personal touch which is undoubtedly attractive to some shoppers; but, as has been shown in the United States, in the long run, it is hard economic reality that prevails. ${ }^{53}$

Side by side with the difficulties of the retailer are those of the small manufacturer of consumer goods; more and more, we are seeing the growth in the United Kingdom of branded products. ${ }^{54}$ It has even spread to such unlikely articles as furniture. ${ }^{55}$ This phenomenon has been accentuated by (I) the remarkable development experienced in the United Kingdom within the last few years in prepackaging, and (2) the impact of national advertising, particularly through the medium of commercial television. ${ }^{56}$ The branding of goods, with all that this involves, is generally quite outside the scope of the small firm. It is one thing to sell one's products to a

${ }^{40}$ In the case of the grocery trade, the cost of labor represents a remarkably large proportion of total costs.

${ }^{50}$ The Economist for Aug. 23, $x 958$ cites the case of a supermarket grossing during the course of a year $19 \%$ against an average of $17.7 \%$ for the counter-service branches of six grocery multiples. The position of supermarkets is helped by their entry into trades such as butchery, green grocery, and the nonfood trades generally, where profit margins are traditionally higher.

${ }^{\mathrm{i}}$ Even if he adopts the small-scale self-service approach, although his turnover will increase, he will still not effect sufficient savings in his running costs to be able to compete with the price-cutting techniques of the supermarket.

${ }^{2}$ When the end of food rationing brought about a swing to main-street shopping and restrictions on building were removed.

${ }^{3}$ At the moment, there are estimated to be only about 200 supermarkets in existence in the United Kingdom. The scope for expansion is, therefore, immense, and at least 5 new ones are being opened each month. Morcover, it is reasonable to assume that the trend will be accentuated by the recent relaxation in credit restrictions for capital projects.

Es This development is already stronger in Great Britain than anywhere else.

"E.g., "G-Plan" \& "Link" furniture.

${ }^{t 0}$ The fact that commercial television is still only received by some $35 \%$ of British homes shows what potential still remains for the exploitation of branded goods from this quarter. See also Lloyd, Some Comments on the British Television Act, 1954, 23 LAw \& Contemp. Prob. 165 (1958). 
wholesaler and leave the distribution to him; it is quite another to assail the retailer directly and force him to stock one's goods by virtue of the public demand engendered through advertising and other means. The cost of branding and the organization it entails is quite prohibitive. Thus, advertising on commercial television at a peak period on Sunday is $£ 4,000$ per minute, ${ }^{57}$ and results will not be forthcoming in the absence of a prolonged and sustained campaign. Indeed, the technique of branding is advancing the interests of the big units in industry, but sounding the death-knell of the small concern.

\section{B. Antitrust Legislation}

The above-mentioned forces which are at work to undermine the position of the small business are further strengthened, it is submitted, by the Restrictive Trade Practices Act, 1956.58 Under part two of the Act, agreements for the collective enforcement of fixed prices by way of collective withholding of supplies (or conversely by way of collective refusal to order supplies) or by any other means are rendered illegal; and it is from the collective enforcement of price-maintenance agreements that the small trader has in the past derived great protection. Accordingly, the restriction on the power of the trade association to impose sanctions on retailers who do not comply with minimum price agreements or on suppliers who do not attempt to ensure compliance with such agreements by their distributors will, it is submitted, adversely affect the interests of small traders who are unable to compete with the price-cutting of the supermarkets or of the giants of the trade generally. ${ }^{59}$

Admittedly, under section 25 of the Restrictive Trade Practices Act, each individual supplier may bring enforcement proceedings to ensure that his goods are not sold below the agreed minimum, but there is absolutely no guarantee that he will use the weapon reserved to him indiscriminately against small and large trader alike. Under subsection (4) the remedy of injunction is subject to judicial discretion, so that a supplier could not hope to obtain such a remedy against the small distributor, but not the large; or against independent traders, but not against members of his own distributive organization. Nevertheless, total inactivity militates against the interests of the small business. In other words, the provisions of section 25 offer little guarantee of protection for the small trader.

But more serious is section 26 of the Restrictive Trade Practices Act, 1956. For subsection (I) specifically envisages that suppliers will, on occasion, allow discounts on resale, and thereby encourages the supermarkets, claiming lower costs of distribution, to put pressure upon suppliers to permit them to sell goods well below their listed price. Moreover, since the amount of discount allowable is under the section on enforceable conditions of re-sale, any disparity of treatment by the supplier

\footnotetext{
${ }^{57}$ For 30 seconds, it can amount at peak periods during the weekdays to $£ 2,500$. Rates in provincial areas only are, of course, less.

${ }^{58} 4$ \& 5 Eliz. 2, c. 68.

${ }^{6}$ E.g., the co-operative societies.
} 
between small and large retailer is capable of being judicially upheld. Needless to say, such a provision deals a shattering blow to the small business unable to compete with this kind of competition.

Finally, under subsection (2) of section 26, subsidiary companies are deemed to be one with their parent company and each other. Accordingly, where great retailing groups are trading, their various constituent units, though operating commercially as separate entities, can (unlike independent factors) still legally combine together to exert pressure on suppliers, whether in the form of demands for more favorable treatment in the discounts allowable on re-sale or, if it suits them better, in the form of insistence that energetic steps be taken to ensure compliance by all retailers with price-maintenance agreements. Once again, the new Act operates in favor of the large organization at the expense of the small retailer.

\section{Hire-Purchase and Credit Sales}

One further economic handicap under which the small enterprise labors should be adverted to at this point. An ever-increasing amount of business is being conducted on a hire-purchase or credit sale basis. ${ }^{60}$ Indeed, the importance of such credit facilities in promoting consumption is fully appreciated by the Treasury, and during the "credit-squeeze" period through which the United Kingdom has just passed, official acknowledgment was paid to the influence on the economy of hirepurchase trading by the imposition of high minimum deposits and the restriction of credit to a maximum of two years. Thus, although the national hire-purchase debt per person is only about one-sixth of that prevailing in the United States, it is still a very significant factor in the United Kingdom's economy; ${ }^{61}$ and it is liable to assume an ever-increasing importance.

The conditions under which goods are sold on a deferred-payments basis are just as important to a person intending to purchase this way as are the cash terms to one who stands in no need of credit; and, needless to say, such baits as "no deposit" and "no service charge," or a comparatively low one such as five per cent per annum or less, have a very material bearing on sales. Moreover, the recent battle over service charges which has flared up in the United Kingdom (sparked off by the entry of the commercial banks into hire-purchase ${ }^{62}$ finance and highlighted by the popular press) has made the public particularly alive to these considerations. However, to be able to offer this kind of inducement, the distributor must be able to command the requisite financial resources, and here again, the small business is at a severe disadvantage. Whereas the large concern can afford to finance its own hire-purchase credit, and thereby fix its own terms, the small business is dependent on a finance house, which is, of course, concerned with making a profit out of its lending activities

${ }^{00}$ Of the total business concluded by household goods shops in August 1958, some $31 \%$ was transacted in this way. Since then, the relaxation of credit restrictions will have increased the proportion.

${ }^{01}$ In December 1958 , it amounted to $£ 604$ million. It rose by $£$ r20 million during this year, $\$ 77$ million of it in the last two months, when credit restrictions had been lifted.

Ba Both by their taking up shares in established finance houses and, in some cases, by their directly competing (offering roughly comparable credit facilities, but at the low rate of $5 \%$ per annum). 
and not in increasing consumer sales. Moreover, the intrinsic overhead costs involved in the collection of hire-purchase debts may often be higher for a finance house than it is for the retailer (if he has the resources to be able to do it himself), because of his greater familiarity with and closer relationship to the actual customer. The result is, then, that the larger distributor who can finance his own hire-purchase sales has a distinct trading advantage over the small retailer who depends on a finance house and cannot offer to his customers such attractive credit facilities as his larger rivals. ${ }^{\text {B3 }}$

\section{IV}

\section{The Soctal and Political Environment}

We must now leave the economic difficulties that confront the small business and turn to consider its position in the social and political environment of today. Socially, the small business is laboring under one particularly severe handicap as against its larger counterpart. The mere size of the big industrial organization renders it socially essential that it should remain in existence. Society cannot allow hundreds or thousands of men and women to be rendered jobless because of the break-up of the company for which they work. Thus, the large concern is, for social reasons, in a strong position to demand bank accommodation (both for immediate working capital and for commitments entered into for the acquisition of buildings and plant) and, when once it has obtained such accommodation, to insist on its continuance and, if need be, its enlargement. The banks cannot withdraw support-not merely because they would be in danger of losing loans already made, but more particularly for the social repercussions that would ensue from such action. Again, a large company is in a position to apply moral pressure on government departments and local authorities for the granting of orders. Or again, if the big organization has got itself well and truly into difficulties, it will almost certainly be taken over by a healthier and more virile enterprise, ${ }^{64}$ and its continuity of existence will be preserved.

In contrast, the small business is unable to invoke social considerations. In fact, so far from winning sympathy, its management will generally incur the wrath of public criticism for ever having allowed the business to get into difficulties. The social considerations are not present to act as a mollifying force. Moreover, where artificial economic situations are brought into being by government policy, the small business, through its inability to call social considerations to its aid, may be at a severe disadvantage as against its larger rival. For example, during the "creditsqueeze" period from which the United Kingdom has just emerged, there is some evidence to suggest that the banks were tougher in their lending policy towards

\footnotetext{
${ }^{\text {os }}$ Moreover, the smaller company may find itself unable to withstand the vagaries of government policy in the fixing of minimum hire-purchase deposits. Sudden alterations in consumer demand artificially produced may ruin a small company unable to weather the storm. Thus, it has been estimated that during the last 8 years, three manufacturers a week in the furniture trade (very much the plaything of government hire-purchase regulations) have been put out of business.

os Just as building societies that have become financially embarrassed might be taken over by sounder societies in the interests of public confidence in the whole movement.
} 
the small company than the large. Moreover, even if equality of treatment be assumed, the mere restriction of bank credit operates more severely against the small concern than the large. As we have demonstrated above, the private company cannot normally approach the London money market for funds, and so depends much upon bank credit.

Finally, we have to consider the small business in the current political climate. The present government, drawn from the Conservative party, is pledged to the granting of the maximum degree of freedom compatible with the public welfare. For the proper regulation of the economy, the Conservative government puts its faith in monetary controls rather than in the so-called planned economy, which depends on licensing and restrictions on commodity imports, building projects, and the like. Thus, politically (within the limits prescribed by any current monetary regulation), the way is wide open for intense competition between rival businesses, and the small company has the opportunity of either going forward and expanding or else of facing extinction. Should, however, a Labor government be returned at the next election and the doctrine of the planned economy be implemented, what will be the position of the small business?

Historically, the Socialists, with their accent on nationalization and on the cooperative movement, have lent little support to the evolution, growth, and development of the small business. Nevertheless, and whatever the theory of Socialism, it is submitted that the principal effect of a planned economy, as far as the small business is concerned, will be that commercial life will tend to be held in its present groove. Licensing and the other controls of a planned economy are invariably operated on the basis of existing size and, by their very nature, are usually not sufficiently flexible to take into account the inherent propensity of the small business to expand or contract rapidly in response to changes in its managerial structure, its financial resources, or economic potentialities. A planned economy stifles movement upwards or downwards and lends full support to the status quo. Whether this is an advantage or disadvantage to the small business (as distinct from the wider and highly debated question of whether it is a benefit to the community at large) must presumably depend on the ambition or caution of the company's management. All that we can say by way of general observation is that the problems facing small business will undoubtedly change with the political theory of the particular government in power at any particular time and that a company's management cannot afford to neglect the present and future political patterns of the economy.

\section{SUMMARY}

We see from our short survey of the present-day position of the small business in the United Kingdom that its problems are manifold and various. Although it may function in the shape of a sole trading concern, a partnership, or a limited company (each of which forms has its own advantages and disadvantages), the small business can conveniently be defined as any enterprise which does not enjoy the benefit 
of a public quotation for its share capital. Generally, the small business will take the form of a private limited company, and the status it thereby assumes imposes upon it certain severe handicaps. Quite apart from its inevitable exposure to the possibility of family feuds and its dependence on the personality of its managing director, it will meet with immense difficulty in finding permanent capital. Indeed, the only really sure way of accumulating permanent funds is by the retention of past profits. Here again, however, the success of this policy will depend on the extent to which present taxation allows the private company to plough back its earnings; and the way in which the small company is taxed more severely than its quoted counterpart is only too clearly in evidence.

Again, if we turn from the difficulties that flow from the mere legal status of the private company and consider its economic problems, we find that as far as the small retailing business is concerned, it is very much at the mercy of the new technological advances in distribution manifested in the rapid expansion of the chain store and the development of the supermarket; and that on the manufacturing side, the small producer of consumer goods is unable to compete with its larger rival in the manufacture of branded products. Moreover, the position is further prejudiced, it is submitted, by part two of the Restrictive Trade Practices Act, 1956, and by the inability of the small retailing concern to offer credit terms as attractive as those of its larger competitor.

If we pass on to social and political considerations, we find the small company brought face to face with further problems. Society cannot permit the dissolution of the large concern, with all that this would imply in terms of unemployment and human misery. The small company, however, is precluded from invoking such sympathetic considerations. As far as politics are concerned, whereas under a Conservative government the small company can reasonably anticipate a high degree of freedom to expand or contract, under Socialist rule the tendency would be for the continuance of the status quo. We see, then, that legally, economically, socially, and politically the small business in the United Kingdom is truly encompassed about by real and significant problems. 